\title{
PENGARUH SPESIFIKASI JABATAN TERHADAP PENEMPATAN PEGAWAI PADA KPP PRATAMA PEMATANGSIANTAR
}

\author{
Oleh: \\ Vivi Pratiwi \\ S1 Manajemen \\ Darwin Lie, Marisi Butarbutar, Efendi
}

\begin{abstract}
Abstraksi
KPP Pratama Kota Pematangsiantar merupakan salah satu Instansi Pemerintah yang bertujuan untuk memberikan pelayanan yang prima bagi seluruh wajib pajak yang terdaftar di KPP Pratama Pematangsiantar. Untuk dapat mencapai tujuan organisasi yang sesuai dengan visi dan misi, maka perlu menempatkan pegawai pada suatu jabatan yang disesuaikan dengan syarat jabatannya. Dimensi spesifikasi jabatan, yaitu pendidikan, pengetahuan, pengalaman, kemampuan dan keahlian, sedangkan dimensi penempatan pegawai, yaitu kesesuaian kesehatan fisik dan mental, dan prestasi kerja.

Hasil analisis menunjukkan pengaruh positif variabel $\mathrm{X}$ dan variabel $\mathrm{Y}$ dengan persamaan $Y=2,55+0,976 X$. Kekuatan hubungan kedua variabel adalah kuat, yaitu sebesar 0,6958. Perhitungan koefisien determinasi menunjukkan bahwa ketepatan penempatan pegawai dapat dijelaskan oleh spesifikasi jabatan sebesar 48,41\%. Untuk itu, penempatan pegawai harus lebih di perhatikan lagi dalam menempatkan seseorang pada suatu jabatan agar tercapainya tujuan utama yaitu pemenuhan target penerimaan pajak yang optimal
\end{abstract}

Kata Kunci: Spesifikasi Jabatan dan Penempatan Pegawai.

\section{Abstraction}

KPP Pratama of Town Pematangsiantar represent one of Government Institution which aim to to give the prima service for all taxpayer enlisted in KPP Pratama Pematangsiantar. To can to reach the organizational target matching with vision and mission, hence require to placed the officer at one particular position which is adapted for by its position condition. Dimension of specification of position, that is education, knowledge, experience, ability and membership, while dimension of officer location, that is according to physical health and bounce, and labour capacity.

Result of analysis show the positive influence of variable of $X$ and variable $Y$ with the equation $Y=2.55+0.976 X$. Second relation strength of variable is strength is equal to 0.6958. Calculation of coefficient determinasi indicate that the explainable officer location accuracy by specification of position of equal to 48.41\%. For that, officer location have to be more in paying attention to again in placing somebody at one particular position to be reaching of especial target that is accomplishment of optimal Iease acceptance goals.

Keyword: Specification of Positionand Officer Location

\section{A. PENDAhUluaN}

\section{Latar Belakang Masalah}

Sumber daya manusia merupakan faktor penting dalam suatu perusahaan, baik perusahaan besar maupun perusahaan kecil untuk mencapai tujuan perusahaan. . Salah satu dimensi untuk merealisasikan tujuan perusahaan tersebut adalah dengan menempatkan karyawan sesuai kebutuhan jabatan tersebut.

Penempatan karyawan adalah tindak lanjut dari seleksi, yaitu menempatkan karyawan yang diterima (lulus seleksi) pada jabatan atau pekerjaan yang membutuhkannya dan sekaligus mendelegasikan authority kepada orang tersebut. Penempatan orang-orang yang tepat pada tempat yang tepat dan penempatan orang yang tepat untuk jabatan yang tepat. Spesifikasi jabatan adalah karakteristik atau syarat-syarat kerja yang harus dipenuhi sehingga dapat melaksanakan suatu pekerjaan/jabatan.
Dalam kenyataannya, fenomena yang terjadi pada KPP Pratama Pematangsiantar menunjukkan masih ada karyawan yang berkerja belum secara efektif, efisien dan produktif dalam menyelesaikan tugasnya. Ada pegawai yang sering menunda-nunda pekerjaan, yang seharusnya diselesaikan dalam satu hari menjadi mundur dalam dua hari atau bahkan lebih. Masih terdapat beberapa pegawai yang mampu tetapi belum tentu ahli, dan sebaliknya. Hal ini disebabkan karena penempatan yang tidak sesuai dengan spesifikasi jabatan yang diduduki oleh pegawai tersebut.

\section{Rumusan Masalah}

Berdasarkan uraian dari latar belakang di atas, maka rumusan masalah penelitian ini adalah: bagaimana pengaruh spesifikasi jabatan (job specification) dan penempatan pegawai pada KPP Pratama Pematangsiantar. 


\section{Tujuan Penelitian}

Adapun tujuan penelitian yang dilakukan adalah sebagai berikut: untuk mengetahui gambaran spesifikasi jabatan dan penempatan pegawai dan untuk mengetahui besarnya pengaruh spesifikasi jabatan terhadap penempatan pegawai pada KPP Pratama Pematangsiantar.

\section{METODE PENELITIAN}

Penelitian ini menggunakan pendekatan penelitian eksplanatoris. Penelitian ini merupakan penelitian populasi, variabel bebas adalah kompensasi dan variabel terikat adalah kinerja karyawan. Teknik pengumpulan data melalui tehnik kuesioner, tehnik wawancara dan dokumentasi. Sumber data dari sumber data primer dan sekunder dengan jenis data kualitatif dan kuantitatif. Selanjutnya data dianalisis dengan metode deskriptip kualitatif dan kuantitatif.

\section{B. LANDASAN TEORI}

\section{Analisa Jabatan}

Menurut Alwi (2001:108), “Analisis jabatan merupakan salah satu aktivitas penting dalam MSDM karena output dari analisis jabatan yang berupa deskripsi jabatan dan spesifikasi jabatan merupakan informasi yang sangat dibutuhkan bagi penentuan strategi penarikan, seleksi, penilaian kinerja, pelatihan dan pengembangan, design, dan redesign jabatan, dan perencanaan sumber daya manusia. Menurut Gomes (2003:91), "Analisis jabatan adalah proses pengumpulan informasi mengenai suatu pekerjaan yang dilakukan oleh seorang pekerja yang dilaksanakan dengan cara mengamati atau mengadakan interview terhadap karyawan, dengan bukti-bukti yang benar dari supervisor. Menurut Nawawi (2005:104), “Analisis jabatan adalah proses menghimpun informasi mengenai setiap jabatan yang berguna untuk mewujudkan tujuan bisnis suatu perusahaan. Sedangkan menurut Mathis (2006:200), "Analisis jabatan adalah sebuah cara sistematis untuk mengumpulkan dan menganalisis informasi tentang isi, konteks, dan persyaratan manusiawi pekerjaan tersebut.

Menurut Alwi (2001:108) menjelaskan bahwa deskripsi dan spesifikasi jabatan, merupakan dua hal yang tidak bisa dipisahkan dalam melakukan analisis jabatan, yaitu:

a. Deskripsi Jabatan

b. Spesifikasi Jabatan

Sedangkan menurut Sihotang (2007:59) menjelaskan terdapat tiga komponen dalam analisis jabatan, yaitu:

a. Deskripsi Jabatan (Job Description)

b. Adalah persyaratan resmi dan terorganisir tentang kewajiban dan tanggung jawab suatu pekerjaannya.

c. Spesifikasi Jabatan (Job Specification)

d. Standar Kinerja Pekerjaan (Performance Standard)

Dari penjelasan diatas dapat diketahui bahwa deskripsi jabatan, spesifikasi jabatan, dan standar kinerja jabatan adalah fakta dalam analisis jabatan.

Menurut Hasibuan (2005:30), menjelaskan bahwa proses dalam menganalisis jabatan melalui tahap-tahap sebagai berikut:

a. Menentukan penggunaan hasil informasi analisis jabatan: adalah penganalisis harus mengetahui secara jelas apa kegunaan hasil informasi analisis jabatannya.

b. Mengumpulkan informasi tentang latar belakang: adalah penganalisis harus mengumpulkan, mengkualifikasi data dan meninjau informasi latar belakang.

c. Menyeleksi jabatan yang akan dianalisis: adalah penganalisis harus memilih beberapa jabatan yang harus dianalisis.

d. Mengumpulkan informasi analisis jabatan: adalah penganalisis kemudian mengadakan analisis jabatan secara aktual dengan menghimpun data tentang aktivitas pekerjaan, perilaku karyawan yang diperlukan,

kondisi kerja, dan syarat-syarat personal yang akan melaksanakan pekerjaan.

e. Meninjau informasi dengan pihak-pihak yang berkepentingan: adalah analisis jabatan menyediakan informasi tentang hakikat dan fungsi pekerjaan.

f. Menyusun deskripsi pekerjaan dan spesifikasi pekerjaan: adalah penganalisis pekerjaan kemudian menyusun deskripsi pekerjaan, spesifikasi pekerjaan, dan evaluasi pekerjaan.

g. Meramalkan perkembangan perusahaan: adalah penganalisis harus juga memperhitungkan atau meramalkan perkembangan deskripsi pekerjaan, spesifikasi pekerjaan, dan evaluasi pekerjaan, apakah dikemudian hari diperlukan pengayaan pekerjaan dalam perusahaan.

Sedangkan menurut Mathis (2006:135), mengembangkan 5 (lima) tahapan dalam proses analisa jabatan yang harus diadakan dengan suatu cara yang efektif, yaitu:

a. Planning the Job Analysis

b. Preparing and Communication the Job Analysis

c. Conducting the Job Analysis

d. Developing Job Descriptions and Job Specifications

e. Maintaining and Updating Job Description and Job Specification

\section{Spesifikasi Jabatan}

Menurut Alwi (2001:108), "Spesifikasi Jabatan adalah uraian tentang kualifikasi pendidikan, pengetahuan, kemampuan, keahlian, dan pengalaman personal yang diperlukan untuk mendukung tugas-tugas kewajiban dan tanggung jawab yang tertuang dalam deskripsi jabatan". Sedangkan menurut Sihotang (2007:59), "Spesifikasi Jabatan yaitu menunjukkan standard manusianya, baik kualitas maupun persyaratanpersyaratan yang dipenuhi pemangku jabatan agar dapat melaksanakan jabatan dengan cukup berhasil. 
Menurut Rivai (2004:126), panduan yang dapat digunakan dalam memasukkan karakteristikkarakteristik yang harus digolongkan pada suatu spesifikasi jabatan yaitu:

a. Semua tugas pekerjaan harus dikenali dan dinilai dalam kaitannya dengan arti penting teknik analisis jabatan;

b. Suatu panel tenaga ahli, karyawan atau para penyelia perlu menetapkan tingkat keterampilan yang diperlukan untuk melakukan masingmasing tugas pekerjaan;

c. Tingkat keterampilan masing-masing harus dinilai;

d. Karakteristik lain yang penting untuk melakukan pekerjaan itu harus dikenali, meliputi: kondisi fisik yang dibutuhkan dan sertifikasi profesional; dan

e. Jenis keterampilan yang telah dikenali perlu untuk secara rinci dikaitkan dengan masingmasing tugas pekerjaan.

Menurut Alwi (2001:109), indikator penilai pekerjaan yang berhubungan dengan spesifikasi jabatan (syarat-syarat jabatan), yaitu terdiri dari:

a. Pendidikan

b. Pengetahuan

c. Pengalaman

d. Kemampuan

e. Keahlian/Keterampilan

\section{Penempatan}

Manullang (2001:3), "Penempatan karyawan adalah suatu fungsi yang penting dalam organisasi manapun dengan tujuan-tujuan yang antara lain meliputi: pemakaian sumber daya manusia maupun sumber daya yang bukan manusia secara efektif". Sedangkan menurut Sastrohadiwiryo (2002:162), "Penempatan karyawan adalah suatu proses pemberian tugas dan pekerjaan kepada karyawan yang lulus dalam seleksi untuk dilaksanakan secara kontinuitas serta mampu mempertanggung jawabkan segala risiko dan kemungkinan yang terjadi atas fungsi dan pekerjaan, wewenang dan tanggung jawab tersebut".

Menurut Hasibuan (2005:64), bahwa penempatan karyawan harus didasarkan pada job description dan job specification yang telah ditentukan serta berpedoman kepada prinsip "Penempatan orang-orang yang tepat pada tempat yang tepat dan penempatan orang yang tepat untuk jabatan yang tepat" atau "The right man in the right place and the right man behind the right job." Prinsip penempatan karyawan yang tepat harus dilaksanakan secara konsekuen, agar supaya karyawan dapat bekerja sesuai dengan spesialisasinya atau keahliannya masing-masing.

Sedangkan prinsip-prinsip yang harus diperhatikan dalam penempatan pegawai menurut Sastrohadiwiryo (2002:185) sebagai berikut:
a. Prinsip kemanusiaan
b. Prinsip demokrasi
c. Prinsip the right man on the right place
d. Prinsip equal pay for equal work
e. Prinsip kesatuan arah

f. Prinsip kesatuan tujuan

g. Prinsip kesatuan komando

h. Prinsip efisiensi dan produktifitas kerja

Menurut Rivai (2004:211) mengemukakan terdapat tiga jenis penempatan, yaitu promosi, transfer, dan demosi.

a. Promosi (Promotion)

b. Transfer

c. Demosi

Menurut Sastrohadiwiryo (2002:162), faktorfaktor yang perlu dipertimbangkan dalam penempatan karyawan adalah sebagai berikut:

a. Faktor Prestasi Akademis

b. Faktor Pengalaman

c. Faktor Kesehatan Fisik dan Mental

d. Faktor Status Perkawinan

e. Faktor usia

Sedangkan menurut Alwi (2001:143), dalam pelaksanaan penempatan karyawan mengemukakan bahwa faktor yang harus dipertimbangkan dalam penempatan karyawan, yaitu sebagai berikut:

a. Faktor prestasi akademis

b. Faktor pengalaman

c. Faktor kesehatan fisik dan mental

d. Faktor usia

Sastrohadiwiryo (2002:166), mengemukakan bahwa sistem penempatan karyawan dapat di definisikan sebagai rangkaian komponen ketenagakerjaan, khususnya dalam menempatkan karyawan yang tepat pada posisi yang tepat, dan dirancang dapat mencapai daya guna dan hasil guna yang sebesar-besarnya sesuai dengan rencana yang telah ditetapkan sebelumnya, yakni sebagai berikut:

a. Haruslah terdapat maksud atau tujuan dalam merancang sistem penempatan karyawan;

b. Haruslah terdapat pendekatan/rancangan komponen ketenagakerjaan; dan

c. Masukkan informasi ketenagakerjaan yang tersedia harus dialokasikan sesuai dengan rencana yang telah ditetapkan terlebih dahulu.

Menurut Sastrohadiwiryo (2002:167), menjelaskan dalam setiap kegiatan diperlukan tahapan yang harus dilalui dalam pelaksanaannya. Tahapan tersebut merupakan urutan kronologis yang dilaksanakan tahap demi tahap (step by step) tanpa meninggalkan prinsip dan asas yang berlaku. Prosedur penempatan karyawan merupakan urutan kronologis untuk menempatkan karyawan pada posisi yang tepat pula.

Menurut Rivai (2004:238), ada beberapa pengukuran atau pertimbangan dalam menempatkan karyawan atau pegawai, yaitu:

a. Kesesuaian: adalah kita menempatkan seseorang sesuai dengan kebutuhan jabatan tersebut atau tidak.

b. Kesehatan Fisik dan Mental: kesehatan fisik dan mental perlu mendapatkan pertimbangan dalam menempatkan karyawan, meskipun kurang akurat terhadap tingkat kepercayaan terhadap hasil tes kesehatan dilakukan terutama kondisi fisik, namun secara sepintas dapat dilihat 
kondisi fisik karyawan yang bersangkutan untuk dipertimbangkan pada bagian mana dia diberikan tugas dan pekerjaan yang cocok baginya berdasarkan kondisi fisik yang dimiliki.

c. Prestasi Kerja: merupakan hasil kerja secara kualitas dan kuantitas yang dicapai oleh seseorang pegawai dalam melaksanakan tugas dan tanggung jawab yang diberikan kepadanya.

\section{PEMBAHASAN}

\section{Analisa}

\section{a. Spesifikasi Jabatan}

Masalah kepegawaian menjadi bahan perhatian penuh bagi pihak kantor. Adapun Departemen yang diserahi untuk mengatur masalah kepegawaian adalah Subbagian Umum dan dipimpin oleh seorang Kepala Bagian Umum yang dibawah dan bertanggung jawab kepada Kepala Kantor dan Direktorat Jenderal Pajak melalui Kanwil Sumatera Utara. Dalam uraian jabatan juga terdapat syaratsyarat jabatan (job specification).

Syarat-syarat jabatan ini menjadi syarat minimum yang harus dipenuhi calon pegawai maupun pegawai dalam pelaksanaan perencanaan jabatan pegawai di KPP Pratama Pematangsiantar dan juga menjadi syarat jabatan yang sudah ditetapkan oleh Direktorat Jenderal Pajak. Syaratsyarat jabatan berisi syarat-syarat minimum yang dapat diterima dan harus dimiliki oleh seorang pegawai untuk melaksanakan pada suatu jabatan tertentu. Syarat-syarat tersebut diantaranya yaitu pengetahuan, pendidikan, pengalaman, kemampuan dan keahlian.

Akan tetapi kualifikasi pendidikan pegawai KPP Pratama Pematangsiantar tidak menjadi syarat pendidikan utama pegawai dalam menduduki jabatan karena kadangkala bisa berubah sesuai dengan kondisi dan kebijakan oleh Direktorat Jenderal Pajak yang dibawah naungan Departemen Keuangan Republik Indonesia.

Dari hasil tabulasi kuesioner diperoleh hasil bahwa kelima indikator (pendidikan, pengetahuan, pengalaman, kemampuan dan keahlian) mayoritas dalam sepesifikasi jabatan sudah baik, walau ada yang perlu diperbaiki.

\section{b. Penempatan Pegawai}

Penempatan pegawai di KPP Pratama Pematangsiantar dapat dilihat melalui dimensi penempatan seperti kesesuaian antara syarat-syarat kerja dengan kesehatan fisik dan mental, serta prestasi kerja pegawai dalam melaksanakan tugas dan pekerjaannya seperti yang ada pada kuesioner.

Dari hasil tabulasi kuesioner diperoleh hasil bahwa ketiga indikator (kesesuaian, kesehatan fisik dan mental, serta prestasi kerja) dalam dalam penempatan pegawai sudah cukup baik, walau masih ada indicator yang perlu dioptimalkan lagi.

\section{c. Regresi Linier Sederhana}

Berdasarkan hasil pengolahan data didapat persamaan regresi linier sederhana sebagai berikut: $\mathrm{Y}=2,55+0,976 \mathrm{X}$. persamaan tersebut bertanda positif, artinya terdapat pengaruh yang positif antara variabel bebas (Spesifikasi Jabatan) terhadap variabel terikat (Penempatan Pegawai) pada KPP Pratama Pematangsiantar. Dimana semakin tepat atau sesuai spesifikasi jabatan yang diterapkan maka semakin tepat penempatan pegawai tersebut.

\section{d. Korelasi dan Determinasi}

Selanjutnya dilakukan perhitungan korelasi berupa derajat atau kedalaman hubungan fungsional yang menjelaskan hubungan antar perubah, dinyatakan dengan yang dinamakan koefisien korelasi yang disimbolkan dengan r. Dari hasil perhitungan diatas, didapat nilai $r=0,6958$ yang artinya terdapat hubungan yang kuat antara variabel $\mathrm{X}$ yaitu Spesifikasi Jabatan terhadap variabel Y yaitu Penempatan Pegawai.

Dari perhitungan koefisien determinasi diatas menunjukkan bahwa ketepatan penempatan pegawai dapat dijelaskan oleh spesifikasi jabatan sebesar $48,41 \%$, sedangkan 51,59 dipengaruhi oleh faktor lain yang tidak dibahas dalam penelitan ini seperti minat, diklat, pangkat/golongan, sifat kepribadian,dan lain-lain. Dengan demikian tingkat hubungan antar variabel adalah sedang.

\section{e. Uji Hipotesis (uji t)}

Uji t digunakan untuk menguji pengaruh variabel bebas terhadap variabel terikat secara parsial atau individual. Dari perhitungan diatas tersebut diperoleh hasil $t_{\text {hit }}(7,75)>t_{\text {tab }}(1,66912)$ maka Ho ditolak dan Ha diterima, artinya variabel spesifikasi jabatan (X) berpengaruh secara positif terhadap variabel penempatan pegawai (Y). Hal ini berarti bahwa spesifikasi jabatan pada KPP Pratama Pematangsiantar berpengaruh secara positif terhadap penempatan pegawai, sehingga hipotesis yang diajukan penulis adalah dapat diterima

\footnotetext{
2. Evaluasi a. Spesifikasi Jabatan

Di dalam spesifikasi jabatan terdapat juga standar kompetensi guna mendukung profesionalisme pegawai dalam melaksanakan tugas-tugas jabatannya. Syarat-syarat jabatan menjadi syarat minimum yang harus dipenuhi calon pegawai dalam pelaksanaan perencanaan jabatan dan juga menjadi syarat jabatan yang sudah ditetapkan oleh Direktorat Jenderal Pajak. Syarat-syarat jabatan berisi syarat-syarat minimum yang dapat diterima dan harus dimiliki oleh seorang pegawai untuk melaksanakan pada suatu jabatan tertentu.

Untuk calon pegawai baru yang akan diangkat menjadi pegawai akan mendapat surat pengangkatan pegawai negeri dan juga surat jabatan oleh pihak Direktorat Jenderal Pajak untuk ditugaskan di KPP Pratama Pematangsiantar yaitu sesuai dengan Peraturan Pemerintah Nomor 13 Tahun 2002 (Lembaran Negara Republik Indonesia
} 
Tahun 2002 Nomor 33. Sedangkan untuk pegawai lama mendapat surat jabatan dari Direktorat Jenderal Pajak yaitu sesuai Peraturan Pemerintah Nomor 9 Tahun 2003.

Indikator spesifikasi jabatan yang diterapkan DJP pada semua KPP Pratama seluruh Indonesia yaitu pendidikan, pengetahuan, pengalaman, kemampuan dan keahlian. Syarat pendidikan minimal Diploma I itupun lulusan dari STAN, sedangkan yang bukan lulusan dari STAN minimal lulusan Sarjana (S1), pegawai menjawab sebagian kecil sangat setuju dan sebagian besar setuju dengan penjelasan nantinya ilmu yang di dapat selama menempuh pendidikan dapat digunakan sebagai bahan untuk melaksanakan dan menyelesaikan tugas kantor, ilmu tersebut juga dapat digunakan sebagai bahan dalam mencapai prestasi kerja pegawai. Akan tetapi kualifikasi pendidikan kadangkala bisa berubah sesuai dengan kondisi dan kebijakan oleh DJP yang dibawah naungan Departemen Keuangan Republik Indonesia.

Indikator pengetahuan, pegawai menjawab sebagian menjawab baik dan ada juga yang menjawab cukup baik. Untuk indikator pengetahuan dengan pernyataan Pengetahuan dapat diperoleh dengan membaca buku-buku umum yang berkaitan dengan perpajakan berada pada nilai rata-rata terendah 2,96 dengan kriteria jawaban Kurang Baik. Hal ini disebabkan pengetahuan tidak hanya di dapat dari buku ataupun ilmu yang ditempuh selama pendidikan, tetapi juga dapat diperoleh dari informasi rekan kerja, pengalaman individu ataupun pengalaman orang lain.

Untuk indikator pengalaman, pegawai menjawab sebagian besar setuju karena pegawai sudah memahami tugas yang nantinya akan menjadi tanggung jawabnya walaupun di Instansi Pemerintah pengalaman tidak begitu dibutuhkan terkecuali di perusahaan swasta. Sedangkan untuk indikator kemampuan, pegawai menjawab setuju karena disini pegawai dituntut untuk mampu dalam menyelesaikan tugas dan pekerjaannya secara efektif, efisien dan produktif. Akan tetapi indikator ini juga memiliki nilai terendah sehingga penilaian Kurang Baik dengan nilai rata-rata 2,90 pada pernyataan Kemampuan pegawai dilihat dari segi pendidikannya. Sebagian responden memberikan saran untuk perbaikan yaitu bahwa kemampuan seseorang tidak bisa hanya diukur dari pendidikannya saja. Karena pendidikan belum menjamin seseorang mampu atau tidak dalam menjalankan tugas dan tanggung jawabnya.

Selanjutnya untuk indikator keahlian, pegawai menjawab setuju karena dalam menempatkan pegawai harus disesuaikan keahliannya agar produktivitas kerja tinggi. Akan tetapi ada pegawai yang mampu tapi belum tentu ahli dan sebaliknya. Untuk itu perlu diperhatikan lagi dalam menempatkan seseorang baik pegawai maupun calon pegawai sesuai dengan kebutuhan jabatan yang diinginkan.

\section{b. Penempatan Pegawai}

Direktorat Jenderal Pajak sangat berperan dalam pengambil kebijakan pada penempatan jabatan dan pengangkatan pegawai KPP Pratama Pematangsiantar sesuai dengan PP No. 9 tahun 2003 pasal 2 dan pasal 3 sebagaimana telah diubah dengan PP No. 63 Tahun 2009, yaitu: Pejabatpejabat yang berwewenang mengangkat para pegawai negeri sipil (PNS), salah satunya adalah Ketua Lembaga atau Sekretaris Dirjen, yang dalam hal ini Sekretariat Direktorat Jenderal Pajak di delegasikan kepada Kanwil Sumatera Utara, kemudian di delegasikan lagi kepada Kepala Kantor KPP Pratama Pematangsiantar.

Jadi calon pegawai dikatakan sah/resmi untuk diangkat menjadi pegawai negeri pajak dan ditempatkan kepada jabatan yang ditentukan, apabila calon pegawai mendapatkan Surat Pengangkatan Pegawai Negeri dan Penempatan Jabatan di KPP Pratama Pematangsiantar dari pihak Sekretariat Dirjen Pajak melewati Kantor Wilayah Sumatera Utara, begitu juga dengan pegawai lama yang akan ditempatkan pada jabatan tertentu atau dipindah tugaskan ke daerah lain akan mendapatkan Surat Jabatan yang dibuat langsung Sekretariat DJP melewati Kanwil Sumatera Utara dan barulah pegawai tersebut dinyatahkan sah/resmi untuk menempati jabatan baru yang telah ditetapkan. Tidak ada batasan waktu tertentu untuk melakukan perubahan pegawai KPP Pratama Pematangsiantar, salah satu diantaranya dalam penempatan pegawai. Semua hal tersebut merupakan ketetapan dari DJP sebagai pengambil kebijakan penuh terhadap pengaturan di KPP Pratama seluruh Indonesia.

Indikator penempatan pegawai yaitu kesesuaian, kesehatan fisik dan mental, dan prestasi kerja. Untuk kategori kesesuaian, pegawai menjawab setuju karena penempatan pegawai disesuaikan dengan kebutuhan jabatan. Sebelum pegawai ditempatkan pada suatu jabatan, terlebih dahulu syarat-syarat kerja harus disesuaikan berupa pendidikan, pengetahuan, kemampuan, dan keahlian dalam melaksanakan tugas dan menyelesaikan pekerjaan secara efektif, efisien dan produktif. Akan tetapi masih ditemukan hambatan yang tidak sesuai dari segi pendidikan (syarat jabatan) pegawai dalam penempatan pegawai, sehingga pegawai sering menunda-nunda pekerjaan yang seharusnya bisa diselesaikan dalam satu hari menjadi mundur dalam dua atau bahkan lebih.

Hal ini bisa disebabkan karena bukan lulusan dari Sarjana yang sesuai dengan bidang pekerjaan tersebut, sehingga pengetahuan yang di peroleh kurang, ilmu yang diperoleh selama pendidikan jauh berbeda dengan pekerjaan yang ditangani pegawai tersebut. Jika pegawai tersebut dibiarkan begitu saja maka tidak akan tercapai tujuan perusahaan baik dalam jangka panjang maupun jangka pendek sesuai dengan visi dan misi KPP Pratama Pematangsiantar, salah satunya yaitu memberikan pelayanan yang prima bagi seluruh wajib pajak yang terdaftar di KPP Pratama Pematangsiantar sehingga timbul kesadaran wajib pajak dalam menjalankan hak dan 
kewajiban perpajakannya secara baik dan benar dalam rangka pemenuhan target penerimaan pajak yang dibebankan kepada KPP Pratama Pematangsiantar.

Untuk mengatasi hambatan tersebut, hendaknya pegawai yang produktivitasnya rendah diberikan usulan diklat agar pegawai tersebut lebih giat dan bersemangat lagi dan mau belajar dari rekan kerja yang satu bagian yang lebih mampu dan ahli dari pegawai tersebut, khususnya dalam bidang perpajakan. Dengan diberikan diklat kepada pegawai tersebut, setidaknya pegawai tersebut akan berusaha memperbaiki kinerjanya sehingga produktivitas kerjanya lebih baik lagi dari yang sebelum memperoleh diklat. Oleh karena itu, syarat jabatan menjadi hal yang paling penting bagi pegawai guna membantu dalam penilaian penempatan.

Untuk indikator kesehatan fisik dan mental, pegawai menjawab setuju karena kesehatan fisik dan mental pegawai harus dipertimbangkan dalam penempatan pegawai dan kesehatan pegawai harus di uji melalui tes kesehatan. Meskipun kurang akurat terhadap tingkat kepercayaan terhadap hasil tes kesehatan dilakukan terutama kondisi fisik, namun secara sepintas dapat dilihat kondisi fisik karyawan yang bersangkutan untuk dipertimbangkan pada tempat mana dia diberikan tugas dan pekerjaan yang cocok baginya berdasarkan kondisi fisik yang dimiliki. Selanjutnya untuk indikator prestasi kerja, pegawai menjawab setuju. Prestasi kerja pegawai merupakan hasil kerja secara kualitas dan kuantitas yang dicapai oleh seorang pegawai dalam melaksanakan tugasnya sesuai dengan tanggung jawab yang diberikan kepadanya. Prestasi kerja pegawai KPP Pratama Pematangsiantar dinilai dengan menggunakan DP3 Pegawai yang bersifat rahasia dan dinilai sekali dalam setahun.

\section{KESIMPULAN DAN SARAN}

\section{Kesimpulan}

a. Spesifikasi jabatan berpengaruh terhadap Penempatan Pegawai di KPP Pratama Pematangsiantar, hal ini dapat dilihat dari hasil pengujian regresi tanda positif pada persamaan sebagai berikut: $\mathrm{Y}=2,55+0,976 \mathrm{X}$.

b. Nilai korelasi yang diperoleh yaitu $r=0,6958$ menunjukkan adanya hubungan yang kuat antara Spesifikasi Jabatan terhadap Penempatan Pegawai. Ketepatan penempatan pegawai dapat dijelaskan oleh spesifikasi jabatan sebesar $48,41 \%$.

c. Hasil uji hipotesis menunjukkan bahwa $t_{\text {hit }}$ $(7,75)>t_{\text {tab }}(1,66912)$ maka Ho ditolak dan $\mathrm{Ha}$ diterima

\section{Saran}

a. Melaksanakan perbaikan kemampuan pegawai tersebut dengan cara menilai ulang kembali pegawai tersebut, atau diberikan diklat agar pegawai tersebut bekerja sesuai dengan kemampuannya.

b. Pegawai diberikan usulan diklat/kursus oleh Kepala Kantor KPP Pratama Pematangsiantar kepada Kantor Pusat melalui Kanwil Sekretariat Dirjen Sumatera Utara.

c. Direktorat Jenderal Pajak dituntut untuk secara bersungguh-sungguh melakukan perubahan dalam manajemen sumber daya manusia demi meningkatkan kapasitas dan kompetensi serta mengoptimalkan sumber daya manusia secara efisien.

d. Menciptakan hubungan yang baik antara pegawai dengan pimpinan, dan sesama pegawai agar dapat menciptakan lingkungan kerja yang kondusif.

\section{E. DAFTAR PUSTAKA}

Alwi, Syafaruddin, Manajemen Sumber Daya Manusia (strategi keunggulan kompetitif), Edisi Pertama, Yogyakarta: BPEE Yogyakarta, 2001.

Gomes, Carduso, Faustino, Manajemen Sumber Daya Manusia, Yogyakarta: CV Andi Offset, 2003.

Handoko, T. Hani, Dasar-Dasar Manajemen, Jakarta: Ghalia Indonesia, 2000.

........ Manajemen Personalia dan Sumber Daya Manusia, Yogyakarta: BPFE Yogyakarta, 2002.

Hasibuan, Malayu S.P, Manajemen Sumber Daya Manusia, Edisi Revisi, Cetakan Kelima, Jakarta: PT. Bumi Aksara, 2002.

Manajemen Sumber Daya Manusia, Edisi Revisi, Cetakan Ketujuh, Jakarta: PT. Bumi Aksara, 2005.

Keputusan Kantor Pusat Direktorat Jenderal Pajak sesuai dengan PP No. 9 Tahun 2003 Pasal 2 dan Pasal 3.

Mathis, Robert L. dan Jackson, John H, Manajemen Sumber Daya Manusia, Jakarta: Salemba Empat, 2006.

Mondy, R. Wayne, Manajemen Sumber Daya Manusia, Jakarta: Penerbit Erlangga, 2008.

Nawawi, Hadari, Manajemen Sumber Daya Manusia untuk bisnis yang kompetitif, Yogyakarta: Gadjah Mada University Press, 2005.

Rivai, Veithzal, Manajemen Sumber Daya Manusia untuk Perusahaan Dari Teori ke Praktik, Jakarta: PT. Raja Grafindo Persada, 2004.

Sastrohadiwiryo, Bedjo Siswanto, Manajemen Tenaga Kerja, Edisi Revisi, Bandung: Sinar Baru, 2002.

Simamora, Henry, Manajemen Sumber Daya Manusia, Yogyakarta: PT. Gramedia, 2004

Sugiyono, Metode Penelitian Kuantitatif Kualitatif dan R \& D, Bandung: Penerbit. Alfabeta, 2008 . 